\title{
Biochemical Impacts of Treating Diabetic Rats with Irradiated Cinnamon
}

\author{
Mohamed H.M. Abd el Megid(1), Ashraf M. Mounir ${ }^{(2)}$, A.M. Abdul Azeem ${ }^{(2) \#}$ and \\ A.N. El shahat ${ }^{(2)}$ \\ (1)Natural Products Department, National Center for Radiation Research and \\ Technology (NCRRT), Atomic Energy Authority (AEA), Cairo, Egypt; (2)Food \\ Irradiation Research Department, National Center for Radiation Research and \\ Technology (NCRRT), Atomic Energy Authority (AEA), Cairo, Egypt.
}

\begin{abstract}
$\mathbf{T}$ HE OBJECTIVES of the present study are to evaluate the effect of $\gamma$-radiation on total phenolic contents of cinnamon dried powder (CDP) and also to investigate the role of raw and $\gamma$-irradiated cinnamon extract (CE) in ameliorating biological disturbances in alloxan-induced diabetic rats. The results obtained show that $\gamma$-irradiation (10kGy) increases the total phenolic contents of CDP by percent change $6.39 \%$. The results revealed also that alloxan administration to rats $(150 \mathrm{mg} / \mathrm{kg}$ B.WT) showed a significant increase in the levels of serum glucose, urea, creatinine, uric acidconcomitant with a significant decrease in the levels of insulin, testosterone $(\mathrm{T})$, serum total thyroid hormones triiodothyronin $\left(\mathrm{T}_{3}\right)$ and thyroxine $\left(\mathrm{T}_{4}\right)$. Furtherer more, alloxan induced asignificant elevation in lipid peroxidation and a reduction in glutathione content and antioxidant enzyme activities in the renal and testicular tissues of diabetic rats. Treatment of diabetic rats with either raw or $\gamma$-irradiated CE has significantly ameliorated the alteration in the antioxidant/oxidant status and improved hyperglycemia, renal, and endocrine abnormalities. In conclusion, the study indicated that cinnamon, in addition to being hypoglycaemic, is effective in reducing oxidative stress caused by alloxan-induceddiabetes and the $\gamma$-irradiation of CPE increased its hygienic quality and significantly its total phenolic content without a significant loss in its quality attributes.
\end{abstract}

Keywords: Cinnamon, Antioxidants, Diabetes, Alloxan, Oxidative stress, Gamma radiation.

\section{Introduction}

Globally, diabetes mellitus (DM) or diabetes is a complex serious health problem group of metabolic endocrine diseases in which a person has high blood sugar, either because the pancreas disorder that hider enough insulin secretion, or because cells do not respond to the insulin that is produced or both (Szkudelska et al., 2014). Hyperglycemia occurs when the cells become unable to utilize glucose and/or the liver and skeletal muscles cannot store glycogen (Luis-Rodríguez et al., 2012). The increased extracellular and intracellular glucose concentrations result in oxidative stress due to increased production of reactive oxygen species (ROS) and diminished in antioxidant body's defenses leading to tissue damage and degenerative complications in many organs, including kidney, testes, heart, muscles, eye, liver and many other organs (Kumar et. al., 2014). Furthermore, DM has adverse effects on male sexual and reproductive functions in diabetic patients and animals (Abdul Nabi et al., 2013). Diabetes-related effects on testicular function have been attributed to the lack of insulin. Also, diabetes may cause alteration in thyroid hormone system by a reduction in the TSH stimulation of the thyroid gland and reduction in generation of $T_{3}$ from $T_{4}$ hormone. There is an alteration in the secretory activity of the thyroid gland and pituitary gland by changing in their structural configuration (Udiong et al., 2007).

Because the synthetic chemical drugs prescribed for treating diabetes have many adverse side effects, therefore there is a great demand to search for alternative safe natural agents from medicinal plants, herbs and spices. Spices have been used since ancient times not only for increasing the flavor of foods, but also for their preservative and medicinal properties. A number of spices and 
herbs have a long history of traditional use in treating elevated blood sugar levels (Sailesh \& Padmanabha, 2014). Cinnamon (Cinnamomum zeylanicum L., Family Lauraceae) is an aromatic phytomedicine herbal medicinal plant used as an anti-diabetic spice (Sailesh \& Padmanabha, 2014). Cinnamon extract decreases blood glucose and increases the insulin sensitivity and glucose uptake in adipocytes (Qin et al., 2003). The polyphenolic contents of cinnamon extracts have been reported to have positive effects in reducing fasting plasma glucose and have hepatoprotective (Moselhy \& Ali, 2009), antioxidant, anti-obesity, hypolipidemic and antidiabetic activities (Azab et al., 2011 and Li et al., 2013).

Gamma irradiation $(\gamma)$ is being used worldwide as a phytosanitory food and herbal material treatment. It is a physical decontamination and preservation method and is currently used by the food and pharmaceutical industry. It improves the safety and hygiene quality of various foods and herbal materials (Mali et al., 2011). There are many studies on the influence of $\gamma$-irradiation on total phenolic compounds and antioxidant activity from several plants and food products. Gamma irradiation (10kGy) has also showed an elevated phenolic acid content in almond skin, cinnamon and clove while phenolic content in nutmeg remained unaltered (Khalaf et al., 2014).

The purpose of this study is to investigate the effects of $\gamma$-irradiation on the total phenolic contents of cinnamon. This is in addition to evaluating the role of $\gamma$-irradiated cinnamon in ameliorating biological disturbances in alloxaninduced diabetic rats.

\section{Materials and Methods}

Chemicals were purchased from Sigma Chemical Co. (St. Louis, MO, USA). Dried cinnamon was purchased from the local market of agricultural herbs, spices and medicinal plants, Cairo, Egypt. The dried plant materials were ground into a fine powder and thereafter subjected to the preparation of aqueous extracts.

\section{Gamma irradiation treatment}

Cinnamon dried powder (CDP) was transferred into polyethylene bags and treated with $10 \mathrm{kGy}$ of gamma rays, using a ${ }^{60} \mathrm{Co}$ source at a dose rate of $1.323 \mathrm{kGy} / \mathrm{h}$ from the Indian unit at the National Center for Radiation Research and Technology (NCRRT),Ciro, Egypt.

\section{Preparation of cinnamon aqueous extracts}

Two hundred grams of the powder of either raw or $\gamma$-irradiated cinnamon CDP were dissolved in $1000 \mathrm{ml}$ distilled water and boiled for $10 \mathrm{~min}$, cooled and filtered using Whatman No. 1 filter paper to obtain $20 \%$ aqueous extract as described by Shalaby \& Hamowieh (2010).

\section{Determination of total phenolic compounds}

The total phenolic contents of raw and $\gamma$-irradiated CDP were determined using the FolinCiocalteau calorimetric method (Tsantili et al., 2010).

\section{Animals and biochemical assay \\ Animals}

Healthy male Wistar rats (170 to $220 \mathrm{~g}$ body weight (B. WT)) were purchased from the Egyptian Holding Company for Biological Products and Vaccines (Cairo, Egypt) and used for the different investigations carried out in the present study. Rats were acclimated to controlled laboratory conditions for two weeks. Rats were maintained on stock rodent diet and tap water that were allowed $a d$ libitum.

\section{Administration of alloxan}

Wistar rats were made diabetic by injecting them with alloxan monohydrate dissolved in saline intraperitoneally with a dosage of $150 \mathrm{mg} / \mathrm{kg} \mathrm{B}$. WT (Pari \& Venkateswaran, 2002). Alloxan can induce fatal hypoglycemia as a result of the massive pancreatic insulin release; therefore, rats were treated with $30 \%$ glucose solution orally at different time intervals after $6 \mathrm{~h}$ of alloxan induction. 5\% glucose solution was kept in bottles in their cages for the next 24h. After one week, blood was extracted from the tail vein for glucose analysis by the method of Trinder (1969). Experimental animals exhibited fasting blood glucose levels in the range of 200 to $250 \mathrm{mg} / \mathrm{dl}$.

\section{Grouping of animals}

The animals were randomly divided into 4 groups, each consisted of 7 rats.

Group A: Healthy rats fed on balanced diet and served as a control, Group B: Diabetic group, Group B + RCE: Diabetic rats received raw cinnamon aqueous extract (RCE) orally at dose $250 \mathrm{mg} / \mathrm{kg} \mathrm{B}$. WT/day (Longe et al., 2015) for 8 weeks and Group B + Irr. CE: Diabetic rats received oral $\gamma$-irradiated 
cinnamon aqueous extract (Irr. CE) $(250 \mathrm{mg} / \mathrm{kg}$ B.WT) for 8 weeks.

At the end of the experiment, animals from each group were sacrificed $24 \mathrm{~h}$ post the last dose of treatment. Blood samples were withdrawn by cardiac puncture after a slight anathesation of rats using diethyl ether, serum and plasma were collected for biochemical analysis. Also, Kidney and testes were removed for biochemical investigation.

\section{Biochemical analysis}

Plasma samples were analyzed for glucose (Trinder, 1969) and insulin hormone was determined by radioimmunoassay kit supplied by Diasari, Italy. Serum total thyroid hormones triiodothyronin $\left(\mathrm{T}_{3}\right)$ and thyroxine $\left(\mathrm{T}_{4}\right)$ levels were measured by in-vitro nuclear diagnostic radioimmunoassay technique as described by Burtis et al. (1994). Estimation of testosterone hormone was performed according to the method by Wilson \& Foster (1992).

Kidney and testes homogenates were obtained using a tissue homogenizer. The homogenates $(1: 10 \mathrm{w} / \mathrm{v})$ were prepared using a $100 \mathrm{mM} \mathrm{KCl}$ buffer (pH 7.0) containing EDTA $0.3 \mathrm{mM}$. All homogenates were centrifuged at $200 \times \mathrm{g}$ for $20 \mathrm{~min}$ at $4^{\circ} \mathrm{C}$, and the supernatants were used to estimate the level of thiobarbituric acid reactive substances (TBARS) (Yoshioka et al. 1979), the activity of xanthine.

Oxidase (XO) and xanthine dehydrogenase (XDH) (Kaminski \& Jewezska, 1979), glutathione (GSH) (Beutler et al., 1963) and for the assays of superoxide dismutase (SOD) (Minami \& Yoshikawa, 1979) and catalase (CAT) activities (Johansson \& Borg, 1988), respectively.

\section{Statistical analysis}

Results were presented as mean $\pm \operatorname{SE}(n=7)$. Experimental data were analyzed using one way analysis of variance (ANOVA). Duncan's multiple range test was used to determine significant differences between means. The statistical analyses were performed using computer program Statistical Packages for Social Science (SPSS) (SPSS, 1998). Differences between means were considered significant at $\mathrm{P}<0.05$.

\section{$\underline{\text { Results }}$}

The present study revealed that $\gamma$-radiation
(10kGy) processing increases the total phenolic contents of raw CDP from $54.8 \mathrm{mg}$ gallic acid equivalent/g to $58.3 \mathrm{mg}$ gallic acid equivalent/g by percent change $6.39 \%$ (Fig; 1).

In this study, induction of diabetes by alloxan led to an increase in the glucose level and reduction in the level of insulin, testosterone $(\mathrm{T})$, serum total thyroid hormones triiodothyronin $\left(\mathrm{T}_{3}\right)$ and thyroxine $\left(\mathrm{T}_{4}\right)$ when compared to control group. Treatment of diabetic rats with either RCE or Irr. CE resulted in a significant decrease in serum glucose level with significant increase in insulin, $\mathrm{T}, \mathrm{T}_{3}$ and $\mathrm{T}_{4}$ concentration in comparison with diabetic rats (Tables 1 and 2).

The data presented in Table 3 indicate that alloxan administration to rats resulted in a remarkable elevation in the serum level of urea, creatinine and uric acid in diabetic rats. Whereas, diabetic rats received oral RCE and Irr. CE exhibited lower levels of urea, creatinine and uric acid than the corresponding value of alloxaninduced diabetic rats.

The results in Table 4 indicate that alloxan administration provoked a significant rise in TBARS level and the activity of XO accompanied by a significant decrease in XDH, SOD and CAT activities and GSH content in examined rat kidney and testes relative to the corresponding values of control rats. On the other hand, an obvious reduction in TBARS level and the activity of XO and a significant elevation in $\mathrm{XDH}, \mathrm{SOD}$ and CAT activities and GSH content were recorded in the kidney and testes of diabetic rats treated with either RCE or Irr.CE relative to the diabetic group (Table 4).

\section{Discussion}

Management of diabetes using agents to devoid of side effects is still a challenge to the medical system. This concern has led to an increased demand for natural products with anti-diabetic activity, having fewer side effects. The anti-diabetic effect of plant extracts could be attributed to their ability to promote regeneration of $\beta$-cells or by protecting these cells from destruction. The biological value of plants depends on their bioactive constituents such as saponins, anthocyanins, flavonoids, polyphenolsditerpenes, triterpenes and other phytochemicals (Patel et al., 2012). 


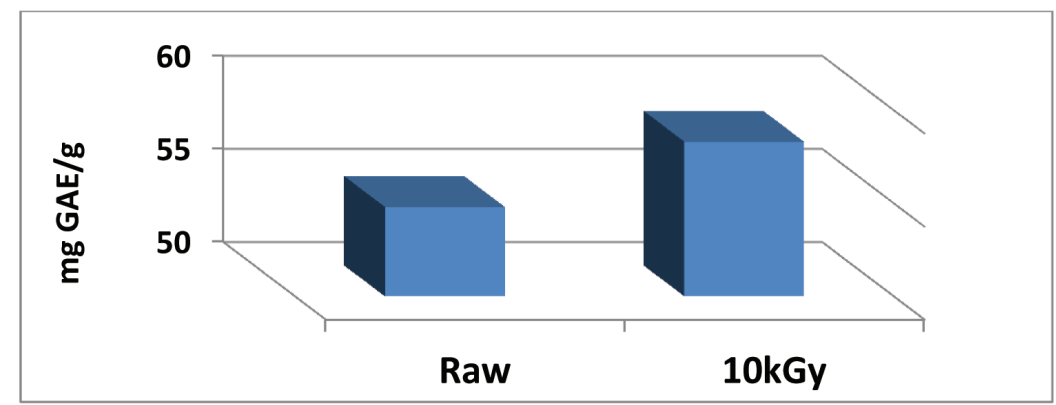

Values are means of three replicates $( \pm \mathrm{SE})$.

Fig. 1. Effect of $\gamma$-radiation on the total phenolic contents of CDP.

TABLE 1. Effect of raw and $\gamma$-irradiated cinnamon extracts on the level of serum glucose and insulin in diabetic rats.

\begin{tabular}{lcccc}
\hline Parameters & A & B & B+RCE & B+Irr. CE \\
\hline Glucose $(\mathrm{mg} / \mathrm{dl})$ & $121.19 \pm 6.8^{\mathrm{d}}$ & $266.23 \pm 7.5^{\mathrm{a}}$ & $161.24 \pm 5.4^{\mathrm{c}}$ & $147.35 \pm 4.8^{\mathrm{b}}$ \\
Insulin $(\mu \mathrm{U} / \mathrm{ml})$ & $32.16 \pm 3.15^{\mathrm{a}}$ & $16.96 \pm 3.36^{\mathrm{d}}$ & $25.46 \pm 2.45^{\mathrm{c}}$ & $28.12 \pm 2.36^{\mathrm{b}}$ \\
\hline
\end{tabular}

Values are expressed as means \pm S.E. $(n=7)$.

Values in the same row with different superscript are differing significantly at $\mathrm{P}<0.05$.

TABLE 2. Effect of raw and $\gamma$-irradiated cinnamon extracts on the level of serum testosterone (T), total thyroid hormones triiodothyronin $\left(T_{3}\right)$ and thyroxine $\left(T_{4}\right)$ in diabetic rats.

\begin{tabular}{lcccc}
\hline Parameters & A & B & B+RCE & B+Irr. CE \\
\hline $\mathrm{T}(\mathrm{ng} / \mathrm{dl})$ & $216.31 \pm 3.63^{\mathrm{a}}$ & $177.21 \pm 3.11^{\mathrm{d}}$ & $190.66 \pm 3.72^{\mathrm{c}}$ & $205.37 \pm 3.81^{\mathrm{b}}$ \\
$\mathrm{T}_{3}(\mathrm{ng} / \mathrm{dl})$ & $88.92 \pm 1.52^{\mathrm{a}}$ & $50.52 \pm 1.64^{\mathrm{d}}$ & $68.82 \pm 1.57^{\mathrm{c}}$ & $73.37 \pm 1.48^{\mathrm{b}}$ \\
$\mathrm{T}_{4}(\mu \mathrm{g} / \mathrm{dl})$ & $7.67 \pm 0.33^{\mathrm{a}}$ & $5.33 \pm 0.38^{\mathrm{d}}$ & $6.17 \pm 0.28^{\mathrm{c}}$ & $6.79 \pm 0.41^{\mathrm{b}}$ \\
\hline
\end{tabular}

Values are expressed as means \pm S.E. $(\mathrm{n}=7)$.

Values in the same row with different superscript are differing significantly at $\mathrm{P}<0.05$.

TABLE 3. Effect of raw and $\gamma$-irradiated cinnamon extracts on the serum level of urea, creatinine and uric acid in diabetic rats.

\begin{tabular}{lcccc}
\hline Parameters & A & B & B+RCE & B+Irr. CE \\
\hline Urea $(\mathrm{mg} / \mathrm{dl})$ & $22.73 \pm 0.92^{\mathrm{d}}$ & $40.27 \pm 1.18^{\mathrm{a}}$ & $29.84 \pm 1.05^{\mathrm{b}}$ & $26.52 \pm 1.12^{\mathrm{c}}$ \\
Creatinine $(\mathrm{mg} / \mathrm{dl})$ & $0.72 \pm 0.04^{\mathrm{d}}$ & $1.31 \pm 0.06^{\mathrm{a}}$ & $1.08 \pm 0.05^{\mathrm{b}}$ & $0.90 \pm 0.05^{\mathrm{c}}$ \\
Uric acid $(\mathrm{mg} / \mathrm{dl})$ & $4.46 \pm 0.26^{\mathrm{c}}$ & $8.29 \pm 0.36^{\mathrm{a}}$ & $5.88 \pm 0.32^{\mathrm{b}}$ & $5.36 \pm 0.30^{\mathrm{b}}$ \\
\hline
\end{tabular}

Values are expressed as means \pm S.E. $(\mathrm{n}=7)$.

Values in the same row with different superscript are differing significantly at $\mathrm{P}<0.05$.

TABLE 4. Effect of raw and $\gamma$-irradiated cinnamon extracts on oxidants and antioxidant levels in the kidney and testes of diabetic rats.

\begin{tabular}{lccccc}
\hline Parameters & & A & B & B+ RCE & B+Irr.RCE \\
\hline TBARS & Kidney & $157.42 \pm 2.12^{\mathrm{d}}$ & $231.62 \pm 4.28^{\mathrm{a}}$ & $194.32 \pm 3.85^{\mathrm{b}}$ & $181.82 \pm 3.57^{\mathrm{c}}$ \\
(n mol/g tissue) & Testes & $128.27 \pm 3.86^{\mathrm{d}}$ & $211.57 \pm 4.56^{\mathrm{a}}$ & $166.42 \pm 3.38^{\mathrm{b}}$ & $150.08 \pm 3.25^{\mathrm{c}}$ \\
XO & Kidney & $1.49 \pm 0.04^{\mathrm{d}}$ & $2.38 \pm 0.06^{\mathrm{a}}$ & $2.03 \pm 0.04^{\mathrm{b}}$ & $1.78 \pm 0.05^{\mathrm{c}}$ \\
(mU/mg protein) & Testes & $1.64 \pm 0.05^{\mathrm{c}}$ & $2.63 \pm 0.07^{\mathrm{a}}$ & $2.11 \pm 0.06^{\mathrm{b}}$ & $1.92 \pm 0.05^{\mathrm{b}}$ \\
XDH & Kidney & $2.73 \pm 0.05^{\mathrm{a}}$ & $1.46 \pm 0.03^{\mathrm{d}}$ & $1.96 \pm 0.04^{\mathrm{c}}$ & $2.23 \pm 0.06^{\mathrm{b}}$ \\
(mU/mg protein) & Testes & $3.46 \pm 0.06^{\mathrm{a}}$ & $1.82 \pm 0.05^{\mathrm{d}}$ & $2.53 \pm 0.04^{\mathrm{c}}$ & $2.86 \pm 0.04^{\mathrm{b}}$ \\
GSH & Kidney & $22.31 \pm 0.88^{\mathrm{a}}$ & $15.82 \pm 0.64^{\mathrm{c}}$ & $18.23 \pm 0.75^{\mathrm{b}}$ & $18.91 \pm 0.81^{\mathrm{b}}$ \\
(mg/g tissue) & Testes & $19.94 \pm 0.52^{\mathrm{a}}$ & $12.11 \pm 0.41^{\mathrm{d}}$ & $15.66 \pm 0.32^{\mathrm{c}}$ & $17.15 \pm 0.38^{\mathrm{b}}$ \\
SOD & Kidney & $27.80 \pm 1.25^{\mathrm{a}}$ & $17.28 \pm 0.94^{\mathrm{d}}$ & $21.51 \pm 1.12^{\mathrm{c}}$ & $23.17 \pm 1.33^{\mathrm{b}}$ \\
(U/mg protein) & Testes & $20.53 \pm 0.60^{\mathrm{a}}$ & $13.14 \pm 0.46^{\mathrm{d}}$ & $16.59 \pm 0.71^{\mathrm{c}}$ & $18.12 \pm 0.47^{\mathrm{b}}$ \\
CAT & Kidney & $37.46 \pm 1.12^{\mathrm{a}}$ & $21.87 \pm 1.01^{\mathrm{d}}$ & $28.86 \pm 1.15^{\mathrm{c}}$ & $31.92 \pm 1.11^{\mathrm{b}}$ \\
(U/g protein) & Testes & $32.55 \pm 0.52^{\mathrm{a}}$ & $17.15 \pm 0.61^{\mathrm{d}}$ & $24.43 \pm 0.58^{\mathrm{c}}$ & $28.71 \pm 0.67^{\mathrm{b}}$ \\
\hline
\end{tabular}

Values are expressed as means \pm S.E. $(n=7)$.

Values in the same row with different superscript are differing significantly at $\mathrm{P}<0.05$. 
The present results indicate that $\gamma$-irradiation of CDP resulted in an increase in the total phenolic content. Villavicencio et al. (2000) concluded that $\gamma$-irradiation could increase the total phenolic contents compared with raw samples and that might be due to the decomposition of some insoluble phenolic compounds or could be attributed to the release of phenolic compounds from glycosidic components and the degradation of larger phenolic compounds into smaller ones by $\gamma$-irradiation (De Camargo et al., 2012).

Results obtained in this study show a significant low level of insulin and high glucose level in the serum of diabetic rats due to alloxan administration. Alloxan-induced diabetes is a well-documented model of experimental diabetes. This effect could be related to alloxan's ability to produce hydrogen peroxide and other free radicals, including $\mathrm{O}_{2} \cdot{ }^{\circ}$ and ${ }^{\circ} \mathrm{OH}$ that damage $\beta$-cells (Lenzen $\&$ Munday, 1991). The sensitivity of $\beta$-cells to oxidative stress has been attributed to their low levels of antioxidants compared with other tissues (Lenzen et al., 1996). $\beta$-celldysfunction eventually culminates in a reduction in insulin release leading to hyperglycemia. The alloxan induced sustained hyperglycemia aggravates the oxidative stress status by auto-oxidation of glucose and its primary and secondary adducts(Sakurai \& Tsuchiya, 1988).

On the other hand, treatment of alloxaninduced diabetic rats with RCE or Irr. CE resulted in an increase in the level of insulin with a significant reduction in the level of glucose. Bugudare et al. (2011) reported that cinnamon has a potential anti-diabetic action in alloxan induced diabetic rats. Both Ping et al. (2010) and Talpur et al. (2005) reported that cinnamon oil can regulate blood-glucose level via improving the function of pancreatic islets and increasing the sensitivity of insulin. High content of polyphenolic compounds of cinnamon may function as antioxidants, potentiate insulin action, and may be useful in the control of glucose intolerance and diabetes (Anderson et al., 2004). Many studies have demonstrated that cinnamon, and its active constituent cinnamaldehyde, improve glycemic control in normal and streptozotocin diabetic rats (Qin et al., 2009). Cinnamon has been shown to reduce fasting serum glucose in patients with type 2 diabetes when it is added to the diet for 40 days at doses of 1,3, or $6 \mathrm{~g}$ (Khan et al., 2003).
The administration of alloxan to male rats induces decreases in $\mathrm{T}_{3}, \mathrm{~T}_{4}$ and testosterone concentrations. The decrease in testosterone concentrations come in agreement with Hurtado deCatalfo \& DeGómez Dumm (1998) which may be the result of both a decrease in the total number of Leydig cells causing strong decrease in the expression of testosterone.

Ward (1991) indicated that alloxan-induced diabetes causes a marked decrease, not only in serum insulin, but also in serum LH levels, which would explain the impairment of Leydig cell function. Sperm production is an FSH-regulated process that requires a normal Sertoli cell function. The decrease in $\mathrm{T}_{3}, \mathrm{~T}_{4}$ and testosterone hormone levels in alloxan injected rats may also be related to the decreased number in Sertoli cells and the damaged Leydig cells that appeared in the testicular tissue sections.

The results of diabetic rats received orally either RCE or Irr. CE obtained that the levels of $\mathrm{T}_{3}, \mathrm{~T}_{4}$ and testosterone were significantly increased relative to the alloxan-induced diabetic rats. The hormonal effect of cinnamon on testosterone could be attributed to cinnamomin and cinnamaldehyde which are the most important components in cinnamon. These compounds effect on the hypothalamus pituitary axis and was increased concentration of $\mathrm{LH}$, FSH and testosterone hormones. Parivzi \& Ellendorff (1982) showed that cinnamaldehyde extracted of cinnamon increase norepinephrine and this hormone can increase LH secretion with activation of nitric oxide. LH hormone affects Leydig cells and this cells release testosterone hormone which is the most important hormones in sex cells proliferation (Shagauo \& Davidson, 2006). Furthermore, several studies indicate that delta-cadenin compound extracted of cinnamon can increase the concentration of testosterone (Sato \& Tsukanmamoto, 2000 and Parvinen et al., 2007).

In this study, the urea, creatinine and uric acid levels, which have been considered significant markers of diabetic nephropathy, increased in the alloxan-induced diabetic group. These results were in accordance with GawrońskaSzklarz et al. (2003) and Yassin (2004). The abnormally high levels of serum creatinine and urea were consistent with the impaired kidney function (Ronco et al., 2010). An elevated urea 
concentration in diabetic rats is associated with greater protein catabolism. Ceriello et al. (2000) demonstrated a positive correlation between hyperglycemia and the development of nephropathy. It has been demonstrated that the metabolic abnormalities observed in uncontrolled diabetes result in gluconeogenesis (Punithavathi et al., 2008) and consequently urea production, which are substantially enhanced in diabetes (Unger \& Orci, 1981)

The data in this work postulated that cinnamon can reduce the serum level of urea, creatinine and uric acid of the diabetic group treated with both RCE and Irr. CE. The nephroprotective effects of cinnamon were previously recorded by El-Yamani (2011) who observed decreased serum urea and creatinine levels in diabetic rats treated with cinnamon. Also, this useful effect of cinnamon was due to its ability in improving renal function and protecting renal glomurlar against oxidative damage via increasing both levels and activities of antioxidant status (Bailey \& Day, 1989).

Concerning the renal and testicular antioxidant status, the current study revealed an increased oxidative stress due to alloxan- induced diabetes, which was evidenced by increased tissue concentration of TBARS and XO activity and depletion of GSH concentration and antioxidant enzymes activity (XDH, SOD and CAT).

The increase in TBARS resulted from hypoinsulinemia that increases the activity of fatty acyl coenzymes A oxidase, which initiates $\beta$-oxidation of fatty acids, resulting in lipid peroxidation. Also, protein glycation and glucose auto-oxidation can lead to the formation of free radicals, and this can equally induce lipid peroxidation (Baynes, 1995). Also, it was observed that the levels of the decrease in antioxidant enzyme activity under diabetic conditions could be due to glycation of these enzymes, which occurred at persistently elevated blood glucose levels (Taniguchi, 1992). Glycation of SOD reduces its activity, leading to the insufficient dismutation of superoxide anions $\left(\mathrm{O}^{-2}\right)$ (Ravi et al. 2004 and Majithiya \& Balaram, 2005), Studies by Young et al. (1995) demonstrated a correlation between improved glycemic control and the inhibition of protein glycation, and hence an increase in SOD activity. Oxidative stress is the result of a redox imbalance between the generation of ROS and the compensatory response from the endogenous antioxidant network.

In this study, the results show that administration RCE and Irr.CE to diabetic rats significantly enhance renal and testicular antioxidant status by increasing tissue GSH concentration and antioxidant enzyme activity (XDH, SOD and CAT) and reducing TBARS concentration and $\mathrm{XO}$ activity. These results could be due to cinnamon flavonoids contents and related compounds such as flavonoids, rosmarinic acid (RA), tannins, coumarins, xanthenes and procyanidins that have been shown to scavenge radicals in a dose dependent manner (Czinner et al., 2000). Ismail (2014) reported that cinnamon and ginger extracts when given to obese diabetic rats induced antioxidant effect that evident by the increased activity of tissue SOD, GPx and CAT antioxidant enzymes in renal tissue. Mang et al. (2006) demonstrated that the antioxidant effect of cinnamon extracts may be attributed to their hypoglycemic activity. Moreover, Mohamed \& Nassier (2013) revealed that intake of cinnamon significantly improved the activity of antioxidant enzymes as well as decreased the production of free radical derivatives and thus helps to treat the damage by free radicals generated during diabetes.

\section{Conclusion}

The results of the present study show that $\gamma$-irradiation of CDP (10 kGy) increased its total phenolic contents. Thus, $\gamma$-irradiated CDP $(10 \mathrm{kGy})$ could be used in various food products as a potential source of natural antioxidants. Also, the findings in this study concluded that either raw or $\gamma$-irradiated cinnamon exhibited anti-diabetic effects and had a renal and testicular protective nature against alloxan-induced diabetic rats due to decreasing the levels of oxidative markers and improvement of natural antioxidants. Also, the findings in this study concluded that either raw or $\gamma$-irradiated cinnamon exhibited anti-diabetic effects and has a renal and testicular protective nature against alloxan-induced diabetic rats due to decreasing the levels of oxidative markers and improvement of antioxidant systems. Also, $\mathrm{CE}$ improved the endocrine disturbance induced by alloxan by increasing the level of insulin, $\mathrm{T}$, $\mathrm{T}_{3}$ and $\mathrm{T}_{4}$ in comparison with diabetic rats. The hypoglycemic and antioxidant potential of $\mathrm{CE}$ could be related to its bioactive contents that have 
the ability to reduced free radicals generation and protect against oxidative stress.

\section{References}

Abdul Nabi, S., Kasetti, R.B., Sirasanagandla, S., Tilak, T.K., Kumar M.V.J. and Rao, C.A. (2013) Antidiabetic and antihyperlipidemic activity of Piper longum root aqueous extract in STZ induced diabetic rats. BMC Complementary and Alternative Medicine, 13, 37.

Anderson, R.A., Broadhurst, C.L., Polansky, M.M., Schmidt, W.F., Khan, A., Flanagan, V.P., Schoene, N.W. and Graves, D.J. (2004) Isolation and characterization of polyphenol type-A polymers from cinnamon with insulin-like biological activity. J. Agric. Food Chem. 52(1), 65-70.

Azab, K.S., Mostafa, A.H., Ali, E.M. and AbdelAziz, M.A. (2011) Cinnamon extract ameliorates ionizing radiation-induced cellular injury in rats. Ecotoxicology and Environmental Safety, 74(8), 2324-2329.

Bailey, C.J. and Day, C. (1989) Traditional plant medicines as treatment for diabetes. Diabetes Care, 12, 553-564.

Baynes, J.W. (1995) Reactive oxygen in the etiology and complications of diabetes. In: "Drug, Diet and Disease: Mechanistic Approach to Diabetes", Ioannides, C. and Flatt, P.R. (Ed.), 2, pp. 203-231. Hertfordshire: Ellis Horwood Limited.

Beutler, E., Duron, O. and Kelly, B.M. (1963) Improved method for the determination of blood glutathione. $J$. Lab. Clin. Med. 61, 882-888.

Bugudare, U.S., Kalyani, D., Krishnaveni, B.R. and Mohd, A. (2011) Influence of hydroalcoholic extract of Cinnamomum cassia on anti-diabetic effect of glibenclamide, metformin alone and their combination. Pharmacologyonline, 2, 798-807.

Burtis, C.A., Shwood, E.R. and Tiel, Z. (1994) "Textbook of Clinical Chemistry", $2^{\text {nd }}$ ed, W. B.Saunders Company, Philadelphia, 1715p.

Ceriello, A., Morocutti, A., Franceschina, M., Quagliaro, L., Moro, M., Damante, G., Viberti, G.C. (2000) Defective intracellular antioxidant enzyme production in type 1 diabetic patients with nephropathy. Am. Diabetes Assoc. 49, 2170-7.
Czinner, E., Hagymasi, K., Blazovics, A., Kery, A., Szake, E., Lemberkovics, E. (2000) In vitro antioxidant properities of Helichrysum aernarium (L.). Moench. J. Ethnopharmacol. 73(3), 437-443.

De Camargo, A.C., De Souza, T.M.F.V. Regitano-D'arce, M.A.B., Calori-Domingues, M.A. and CanniattiBrazaca, S.G. (2012) Gamma radiation effects on peanut skin antioxidants. Int. J. Mol. Sci. 13, 30733084.

EL-Yamani, M.A.S. (2011) Cinnamon, cardamom and ginger impacts as evaluated on hyperglycemic rats, Research of Specific Education Mansoura University, 20, 664-679.

Gawrońska-Szklarz, B., Musiał, D.H., Pawlik, A. and Paprota, B. (2003) Effect of experimental diabetes on pharmacokinetic parameters of lidocaine and MEGX in rats. Pol. J. Pharmacol. 55(4), 619- 624.

Hurtado deCatalfo, G.E. and DeGómez Dumm, I.N.T. (1998) Lipid dismetabolism in Leydig and Sertoli cells isolated from streptozotocin-diabetic rats. International Journal of Biochemistry and Cell Biology, 30, 1001-1010.

Ismail, S.N.(2014) Protective effects of aqueous extracts of cinnamon and ginger herbs against obesity and diabetes in obese diabetic Rat. World Journal of Dairy \& Food Sciences, 9(2), 145-153.

Johansson, L.H. and Borg, L.A.H. (1988) A spectrophotometric method for determination of catalase activity in small tissue samples. Anal. Biochem.74, 331.

Kaminski, Z.W. and Jewezska, M.M. (1979)Intermediate dehydrogenase oxidase form ofxanthine oxidoreductase in rat liver. Biochem. J. 181, 177182.

Khan, A., Safdar, M., Khan, M.M.A., Khattak, K.N. and Anderson, R.A. (2003) Cinnamon improves glucose and lipids of people with type 2 diabetes. Diabetes Care, 26(12), 3215-3218.

Khalaf, H.H., Sharoba, A.M., El Sadani, R.A., El Nashaby, F.M. and Elshiemy, S.M. (2014) Antioxidant properties of some extracts from gamma irradiated tomato(Lycopersicon esculentum L.) pomace. J. Food Dairy Sci. 5, 247-263.

Kumar, R., Iqubal, A., Singh, A.K., Nath, A., Singh, J. 
K., Ali, Md and Kumar, A.(2014) Hypoglycemic and nephroprotective effect of Cinamomum cassia on alloxan induced diabetic mice. International Journal of Diabetes Research, 3(3), 36-40.

Lenzen, S. and Munday, R. (1991) Thiol group reactivity, hydrophilicity, and stability of alloxan, its reduction products and its $\mathrm{N}$-methyl derivatives and a comparison with ninhydrin. Biochem. Pharmacol. 42, 1385.

Lenzen, S., Drinkgern, J. and Tiedge, M. (1996) Low antioxidant enzyme gene expression in pancreatic islets compared with various other mouse tissues. Free Radic. Biol. Med. 20, 463.

Li, R., Liang, T., Xu, L., Li, Y., Zhang, S. and Duan, X. (2013) Protective effect of cinnamon polyphenols against STZ-diabetic mice fed high-sugar, high-fat diet and its underlying mechanism. Food Chemistry and Toxicology, 51, 419-425.

Longe, A.O., Momoh, J. and Adepoju, P.A. (2015)Effects of cinnamon aqueous extract on blood glucose level, liver biomarker enzymes, hematological and lipid profile parameters in alloxan- induced diabetic rats. European Scientific Journal, February /SPECIAL/ edition Vol.1 ISSN: 1857-7881 (Print) e - ISSN 1857- 7431

Luis-Rodríguez, D., Martínez-Castelao, A., Gorriz, J.L., De-Alvaro, F. and Navarro-Gonzalez, J.F. (2012) Pathophysiological role and therapeutic implications of inflammation in diabetic nephropathy. World Journal of Diabetes, 15, 7-18.

Majithiya, J.B. and Balaraman, R. (2005) Timedependent changes in antioxidant enzumes and vascular reactivity of aorta in streptozotocin-induced diabetic rats treated with curcumin. J. Cardiovasc. Pharmacol. 46, 697-705.

Mali, A.B., Khedkar, K. and Lele, S.S. (2011) Effect of gamma irradiation on total phenolic content and in vitro antioxidant activity of pomegranate (Punica granatum L.) peels. Food Nutr. Sci. 2, 428-433.

Mang, B., Wolters, M., Schmitt, B., Kelb, K., Lichtinghagen, R., Schtichtenoth, D.O. and Hahn, A. (2006) Effects of cinnamon extract on plasma glucose, HBA1c and serum lipids in diabetes mellitus type 2. European Journal of Clinical Investigation, 36, 340-344.
Minami, M. and Yoshikawa, H. (1979) A simplified assay method of superoxide dismutase activity for clinical use. Clin. Chim. Acta, 92, 337-342.

Mohamed, N.A. and Nassier, O.A. (2013) Effects Of Cinnamon (Cinnamomum cassiae) And/Or barley (Hordeum vulgare L.) On some physiological parameters In streptozotocin diabetic rats. Egypt. J. Exp. Biol. (Zool.), 9(1), 133-139.

Moselhy, S.S. and Ali, H.K. (2009) Hepatoprotective effect of cinnamon extracts against carbon tetrachloride induced oxidative stress and liver injury in rats. Biology Research, 2(1), 93-98.

Pari, L. and Venkateswaran, S. (2002) Hypoglycaemic activity of Scopariadulcis L. extract in alloxan induced hyperglycaemic rats. Phytotherapy Research, 16(7), 662-664.

Parivzi, N. and Ellendorff, F. (1982) Further evidence on dual effects of norepinphrine on LH Secretion. Neuro Endocrinolog. 35(1), 48-55.

Parvinen, M.K., Vinko, K. and Topari, J. (2007) Cell interaction during the seminiferous epithelial cycle. Cytology, 104, 114-129.

Patel, D., Prasad, S., Kumar R. and Hemalatha S. (2012) An overview on antidiabetic medicinal plants having insulin mimetic property. Asian Pacific Journal of Tropical Biomedicine, 2(4), 320-330.

Ping, H., Zhang, G. and Ren, G. (2010) Antidiabetic effects of cinnamon oil in diabetic KK-Ay mice. Food Chem. Toxicol. 48(8-9), 2344-2349.

Punithavathi, V.R., Anuthama, R. and Prince, P.S. (2008) Combined treatment with naringin and vitamin $\mathrm{C}$ ameliorates streptozotocin-induced diabetes in male wistar rats. J. Appl. Toxicol. 28, 806-13.

Qin, B., Nugasaki, M., Ren, M., Bajotto, G., Oshida, Y. and Sato, Y. (2003) Cinnamon extract (traditional herb) potentates in vivo insulin-regulated glucose utilization via enhancing insulin signaling in rats. Diabetes Research and Clinical Practices, 62, 139148.

Qin, B., Polansky, M.M., Sato, Y., Adeli, K. and Anderson, A.R. (2009) Cinnamon extract inhibits hepostprandial overproduction of apolipoprotein B48-containing lipoproteins in fructose-fed animals. J. Nutr. Biochem. 20(11), 901-908. 
Ravi, K., Ramachandran, B. and Subramanian, S. (2004) Protective effect of Eugenia jambolana seed kernel on tissue antioxidant in streptozotocininduced diabetic rats. Biol. Pharm. 27, 1212-7.

Ronco, C., Grammaticopoulos, S., Rosner, M., Decal, M., Soni, S., Lentini, P. and Piccinni, P. (2010) Oliguria, creatinine and other biomarkers of acute kidney injury. Contributions Nephrol. 164, 118-27.

Sailesh, K.S. and Padmanabha (2014) A comparative study of the anti diabetic effect of oral administration of cinnamon, nutmeg and peppermint in Wistar albino rats. International Journal of Health Sciences \& Research, 4(2), 61-67.

Sakurai, T. and Tsuchiya, S. (1988) Superoxide productin from non-enzymatically glycated proteins. FEBS Lett. 236, 406-410.

Sato, Y. and Tsukanmamoto T. (2000) Effects of nitric oxide stimulation on the brain. Drugs Today, 36(23), 38 .

Shagauo, R.B. and Davidson, A.M. (2006) The effect of Cinnamomum zeylanicum on histological structure of testis in rats. Endocrinology, 63, 241-252.

Shalaby, M.A. and Hamowieh, A.R. (2010) Safety and efficacy of Zingiber officinale roots on fertility of male diabetic rats. Food Chem. Toxicol. 48(10), 2920-4.

SPSS. (1998) Statistical Package for Social Science. Computer Software, Ver. 10. SPSS Company, London, UK.

Szkudelska, K., Nogowski, L. and Szkudelski, T. (2014) Adipocyte dysfunction in rats with streptozotocinnicotinamide induced diabetes. Int. J. Exp. Pathol. 95, 86-94.

Talpur, N., Echard, B., Ingram, C., Bagchi, D., Preuss, H. (2005) Effects of a novel formulation of essential oils on glucose insulin metabolism in diabetic and hypertensive rats: a pilot study. Diabetes Obes. Metab. 7(2), 193-199.

Taniguchi, N. (1992) Clinical significance of superoxide dismutases: Changes in aging, diabetes, ischemia and cancer. Adv. Clin. Chem. 29, 1-59.

Trinder, P. (1969) Determination of blood glucose using 4-amino phenazone as oxygen acceptor. J. Clin. Pathol. 22, 246.

Tsantili, E., Shin, Y., Nock, J.F. and Watkins, C.B. (2010) Antioxidant concentrations during chilling injury development in peaches. Postharvest Biology and Technology, 57, 27-34.

Udiong, C.E.J.A., Udoh, E. and Etukudon, M.E. (2007) Evaluation of thyroid function in diabetes mellitus in calabar, Nigeria. India. J. Clin. Biochem. 22, 7478.

Unger, R.H. and Orci, L. (1981) Glucagon and the cell. II-Physiology and pathophysiology. N. Engl J. Med. 304, 1575-80.

Villavicencio, A.L.C.H., Mancini-Filho, J., Delincée, H. and Greiner, R. (2000) Effect of irradiation on anti-nutrients (total phenolics, tannins and phytate) in Brazilian beans. Radiat. Phys. Chem. 57, 289293.

Ward, D.N., Bousfield, G.R. and Moore, K.H. (1991) Gonadotropins. In: "Reproduction in Domestic Animals", Cupps, P.T. (Ed.), pp. 25-67. San Diego, Calif: Academic Press.

Wilson, J.D. and Foster, D.W. (1992) "Williams Textbook of Endocrinology", pp. 923-926. Philadelphia: Saunders.

Yassin, M., Ashour, A. and Elyazji, N. (2004) Alterations in body weight, protein profile, nonprotein nitrogen constituents and kidney structure in diabetic rats under glibenclamide treatment. $J$. Islam. Univ. Gaza, 12, 65-82.

Yoshioka, T., Kawada, K., Shimada, T. and Mori, M. (1979) Lipid peroxidation in maternal and cord blood and protective mechanism against activatedoxygen toxicity in the blood. Am. J. Obstet. Gynecol. 135, 372-376.

Young, I.S., Tate, S., Lightbody, J.H., Mc Master, D. and Trimble, E.R. (1995) The effects of desferrioxamine and ascorbate on oxidative stress in the streptozotocin diabetic rat. Free Rad. Biol. Med. 18, 833-40.

(Received 31/ 10/2018; accepted 3/12/2018) 
التأثيرات الكيميائية الحيوية لمعالجة الجرذان المصابة بداء السكري بالقرفة المشععة

محمد حسن عبدالمجيد(1)، أشرف محمد منير (2)، على محمد عبدالعظيم(2) و عمرو نجاح الثحات(2)

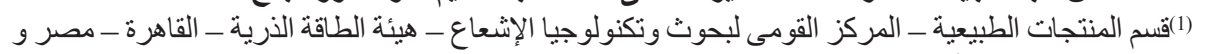

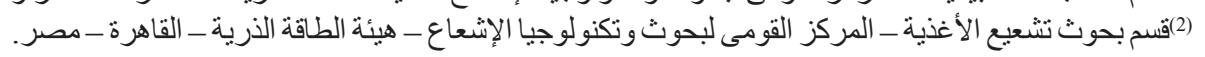

تهدف هذه الدر اسة إلى تقييم تأثير أشعة جاما على المحتوى الكلى للفينولات لمسحوق القرفة المجففة وأيضا

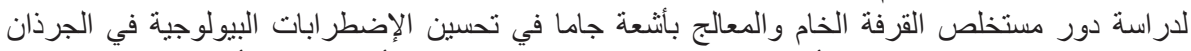

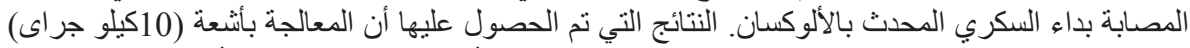

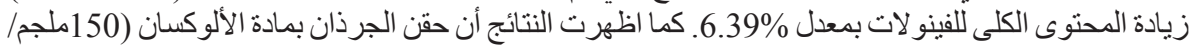

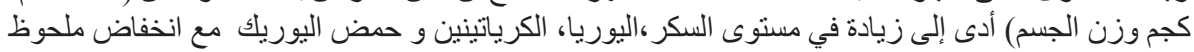

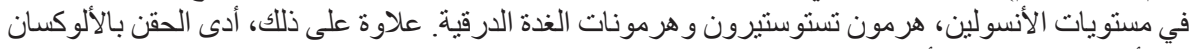

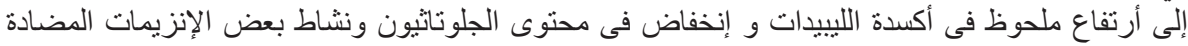

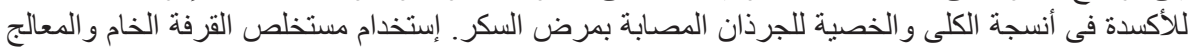

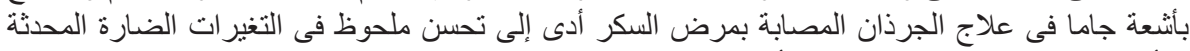

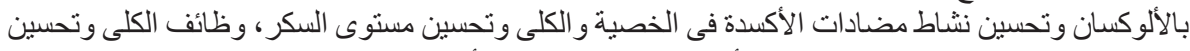

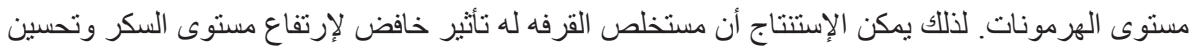

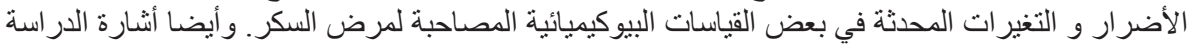

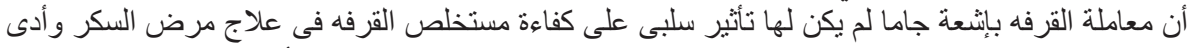

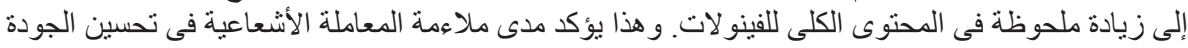
الصحية للقرفه. 